\title{
An Analysis of Maternal Death' Cause in Bandung City (Epidemiology Study in Efforts to Lower Maternal Mortality Rate in West Java Province)
}

\author{
Hartinah$^{1}$, Innama Sakinah ${ }^{2}$, Tita Husnitawati Madjid ${ }^{3}$, Hadi Susiarno ${ }^{4}$, Hadyana \\ Sukandar ${ }^{5}$, Agnes Dwi H ${ }^{6}$, Herry Herman ${ }^{7}$ \\ ${ }^{1}$ Midwifery Study Program, Faculty of Medicine, Padjadjaran University \\ ${ }^{2}$ Faculty Of Health Sciences, Universitas Faletehan \\ ${ }^{3}$ Department of Obstetrics and Gynecology, Padjadjaran University \\ ${ }^{4}$ Department of Obstetrics and Gynecology, Padjadjaran University \\ ${ }^{5}$ Department of Community Health, Padjadjaran University \\ ${ }^{6}$ Department of Obstetrics and Gynecology, Bandung City Maternal and Child Health Hospital \\ ${ }^{7}$ Department of Orthopedics and Traumatology, Faculty of Medicine, Padjadjaran University, UNPAD / \\ RSHS \\ *innamasakinah@yahoo.com
}

\begin{abstract}
Maternal mortality has been a global problem and especially occurs in developing countries, including Indonesia. West Java Province is one of the provinces with high mortality cases in Indonesia. Most of the causes of maternal deaths should be preventable, it can be from patients, health workers, infrastructure, and referrals. The purpose of this study was to determine the relationship between preventable and non-preventable causes of death with the characteristics of the mother, health personnel, referrals, facilities and infrastructure. The research design was analytic observational with a case control design. The number of samples in the case group was 26 cases and the control group was 78 cases. The data analysis used was univariate, bivariate analysis with the chi square test. The results showed that the factors associated with maternal mortality based on the analysis were history of ANC $(\mathrm{OR}=37.4 ; 95 \% \mathrm{CI}: 9.5$ - 313.6; $\mathrm{p}=0.012)$, place of death $(\mathrm{OR}=$ 21.5; 95\% CI: 2.5 - 188.5; $\mathrm{p}=0.001)$, Health Facility (OR = 21.5; 95\% CI: $2.5-188.5 ; \mathrm{p}=$ $0.001)$, Non-referral case $(\mathrm{OR}=91.2 ; 95 \% \mathrm{CI}: 11.1-750 ; \mathrm{p}=0.001)$, delay in referral $(\mathrm{OR}=122.1 ; 95 \% \mathrm{CI}: 14.7-1010.2 ; \mathrm{p}=0.001)$. The results of the qualitative study showed that maternal mortality was affected by several factors, such as the low level of understanding of danger signs in pregnancy, labor and childbirth, low levels of late referral by overdue family decisions. The delay in decision making was due to the lack of ability of health workers to provide information to families in understanding the danger signs in pregnancy, labor and childbirth, so there is a need for IEC / counseling for pregnant, childbirth and postpartum mothers, especially for mothers and families at high risk pregnancy / having complications.
\end{abstract}

Keywords: Maternal Death, Cause Of Maternal Death, Epidemiology Study 


\section{STRADA Jurnal Ilmiah Kesehatan}

DOI: $10.30994 /$ sjik.v9i2.469

ISSN: 2252-3847 (print); 2614-350X (online)

Vol.9 No.2 November 2020 Page.1370-1379

\section{BACKGROUND}

The success of health development is determined by the continuity between program and sector efforts, as well as the continuity with the efforts that have been implemented by the previous period (Indonesia KKR, 2015).

One of the degrees of community health in Indonesia is illustrated by the mortality rate which consists of the maternal mortality rate (MMR), neonatal mortality rate (NMR), infant mortality rate (IMR), and under-five mortality rate (UMR) (Indonesia Health Profile 2012, 2013)

Based on World Health Organization (WHO) data, maternal / maternal mortality has decreased by $43 \%$ from an estimated 532,000 in 1990 to 303,000 in 2015. According to the World Health Organization (WHO), in 2013 the maternal mortality rate in the world 210 / 100,000 live births (LB), MMR in developing countries 230 / 100,000 and MMR in developed countries 16 / 100,000 LB. MMR in East Asia 33 / 100,000 LB, South Asia 190 / 100,000 LB, Southeast Asia 140 / 100,000 LB and West Asia 74 / 100,000 LB. Meanwhile, MMR in Indonesia based on the Indonesian Health Demographic Survey (IDHS) in 2012 was 359 / 100,000 KH. If it is compared to Malaysia, the Philippines, and Singapore, this figure was bigger than the figures for these countries, where the MMR in Malaysia was 29 / 100,000 LB, the Philippines 120 / 100,000 LB, and Singapore 6 / 100,000 LB (WHO, 2014).

In West Java, based on data from district / city health offices, the number of maternal deaths in 2014 was 748 cases out of 954,141 live births, so that the maternal mortality rate in West Java in 2014 was 78.69 / 100,000 KH. This figure has decreased compared to 2013 which reached 82.7 / 100,000 LB (West Java Health Profile, 2014).

The number of maternal deaths in Bandung City in 2013 was reported as many as 25 cases of death and in 2014 it increased to 30 maternal deaths, while in 2015 it decreased again to 26 maternal deaths.

Based on the health profile of Bandung City in 2015, the number of mothers who gave birth was 46,128 deliveries. Meanwhile, the maternal mortality rate in Bandung is 56 out of 100,000 live births.

The end of the MDG's program in 2015 changed the mindset of the world to transform with the sustainable development agenda in 2016 called Sustainable Development Goals (SDGs) which apply to all developed and developing countries for the next 15 years or until 2030. The target of reducing MMR is less of 70 / 100,000 live births and IMR less than 12/1000 live births (WHO, 2015).

Based on the maternal audit, data on maternal mortality was obtained due to 3 (three) delays, they are being late in recognizing the danger signs of childbirth and making decisions, being late in referring and being late in handling by health workers in health facilities. Maternal mortality was also caused by 4 too much, namely too old pregnant (pregnant over 35 years) as much as $27 \%$, too young to get pregnant (pregnant under 20 years) by $2.6 \%$, and too much (number of children more than 4 ) as much as $11,8 \%$ and too close (distance between births less than 2 years) (Jablensky A, 1989).

From the causes above, maternal mortality can be divided into preventable and nonpreventable deaths. A preventable death is also known as preventable maternal death or avoidable factors, is a maternal death that could have been prevented if the patient received help or came at the right time so that he could be helped professionally with adequate 


\section{STRADA Jurnal Ilmiah Kesehatan}

DOI: $10.30994 /$ sjik.v9i2.469

ISSN: 2252-3847 (print); 2614-350X (online)

Vol.9 No.2 November 2020 Page.1370-1379

facilities and facilities. Meanwhile, death that cannot be prevented or unpreventable maternal death is maternal death that cannot be avoided even though all good efforts have been made (Merali HS, et al, 2014).

\section{METHODS}

This type of research is analytic observational research, with a case control study design. In addition, a qualitative study was also conducted using in-depth interviews with respondents to maternal death cases to complete information on the chronology of maternal deaths, as well as interviews with hospitals, health offices and village midwives regarding maternal health service efforts carried out by the city of Bandung in order to lower maternal mortality (Bandung City Profile, 2014).

A case-control study was conducted by identifying a case group (maternal mortality) and a control group (living postpartum mothers), then retrospectively (backward tracing) investigated risk factors that might explain whether cases and controls were exposed or not.

The sample the case was total sampling; it was all maternal deaths in the city of Bandung in 2015 as many as 26 people, while the control sample were $3 \times 26$ people $=78$ people. The dependent variable was maternal mortality, while the independent variable was the patient's factor, they are characteristics which include age, parity, birth spacing, education, history of maternal disease, and also history of ANC, facilities and infrastructure, and referral system.

Quantitative data analysis was carried out by univariate and bivariate (Chi Square test). Qualitative data analysis was descriptive and presented in narrative form.

The research was conducted in Bandung City, West Java Province, from November to December 2016. In this study, the selection of districts / cities that will be used as research sites using cluster techniques based on the highest number of maternal deaths in 27 districts / cities of West Java Province.

\section{RESULTS}

Table 1. Patient factors in terms of patient characteristics, birth attendants, place of death, and availability of facilities

\begin{tabular}{|c|c|c|c|}
\hline No. & Variable & $n=26$ & Percentage (\%) \\
\hline \multirow[t]{3}{*}{1.} & Mother's age & & \\
\hline & $<20$ years old and $>35$ years old & 10 & 38,5 \\
\hline & $20-35$ years old & 16 & 61,5 \\
\hline \multirow[t]{3}{*}{2.} & Parity & & \\
\hline & 1 or $\geq 4$ children & 8 & 30,8 \\
\hline & $2-3$ children & 18 & 69,2 \\
\hline \multirow[t]{3}{*}{3.} & Birth space & & \\
\hline & $<2$ years & 7 & 26,9 \\
\hline & $\geq 2$ years & 19 & 73,1 \\
\hline \multirow[t]{4}{*}{4.} & Mother's education & & \\
\hline & Primary & 8 & 30,8 \\
\hline & Secondary & 14 & 2,7 \\
\hline & High & 4 & 15,4 \\
\hline \multirow[t]{3}{*}{5.} & Maternal comorbidities & & \\
\hline & Yes & 4 & 15,4 \\
\hline & No & 22 & 84,6 \\
\hline
\end{tabular}




\section{STRADA Jurnal Ilmiah Kesehatan}

DOI: $10.30994 /$ sjik.v9i2.469

ISSN: 2252-3847 (print); 2614-350X (online)

Vol.9 No.2 November 2020 Page.1370-1379

\begin{tabular}{|c|c|c|c|}
\hline 6. & $\begin{array}{r}\text { ANC history } \\
<4 \text { times }\end{array}$ & 8 & 30,8 \\
\hline & $\geq 4$ times & 18 & 69,2 \\
\hline \multirow[t]{3}{*}{7.} & Birth Attendants & & \\
\hline & Non health worker & 0 & 0 \\
\hline & Health worker & 26 & 100 \\
\hline \multirow[t]{4}{*}{8.} & Death place & & \\
\hline & House & 4 & 15,4 \\
\hline & In course & 1 & 3,8 \\
\hline & Hospital & 21 & 80,8 \\
\hline \multirow[t]{3}{*}{9.} & Facility availability & & \\
\hline & Available & 5 & 19,2 \\
\hline & Not available & 21 & 80,8 \\
\hline
\end{tabular}

Table 1. presented data on maternal mortality mostly in mothers aged 20 - 35 years were 16 cases, parity $2-3$ were 18 cases $(69.2 \%)$, most birth spacing $\geq 2$ years 19 cases (73.1\%), Most maternal education was secondary education were 14 cases $(2.7 \%)$, comorbidities were 4 cases $(15.4 \%)$, history of ANC $<4$ times were 8 cases $(30.8 \%)$, the majority of maternal deaths occurred in hospitals were 21 cases $(80.8 \%), 26$ cases $(100 \%)$ assisting delivery by health workers, and 21 cases $(80.8 \%)$ for the availability of facilities.

Table 2. Frequency Distribution of Causes of Maternal Death in Bandung City

\begin{tabular}{llcc}
\hline No & \multicolumn{1}{c}{ Causes of maternal death } & Total & \% \\
\hline 1. & direct obstetric death & 10 & 38,5 \\
& a. Bleeding & 7 & 27 \\
b. Preeclampsia / Eclampsia & 4 & 15,4 \\
c. Infection & 1 & 3,8 \\
d. Embolism & & 7,7 \\
2. indirect obstetric death & 2 & 3,8 \\
a. Heart disease & 1 & 3,8 \\
b. Bronco pneumonia & 1 & $\mathbf{1 0 0}$ \\
c. Anemia & $\mathbf{2 6}$ & \\
\hline
\end{tabular}

From this table, it can be seen that the most common causes of maternal death were due to direct obstetric complications as many as 22 cases $(84.1 \%)$.

Table 3. Profile of Causes of Maternal Death Direct Causes that can be Prevented in the City of Bandung

\begin{tabular}{|c|c|c|c|c|c|c|}
\hline \multirow{3}{*}{ No } & \multirow{3}{*}{ Category } & \multicolumn{4}{|c|}{ Direct causes $n=22$} & \multirow{3}{*}{$\begin{array}{c}\text { Tota } \\
\text { n }\end{array}$} \\
\hline & & Bleeding & $\begin{array}{c}\text { Preeclampsia/ } \\
\text { Eclampsia }\end{array}$ & Infection & Emboli & \\
\hline & & $\mathbf{n}$ & $\mathbf{n}$ & $\mathbf{n}$ & $\mathbf{n}$ & \\
\hline \multirow[t]{3}{*}{1} & Maternal Death & & & & & \\
\hline & Unpreventable & 5 & 4 & 1 & 1 & 11 \\
\hline & ricese & 5 & 3 & 3 & 0 & 11 \\
\hline \multirow[t]{4}{*}{2} & Death place & & & & & \\
\hline & House & 0 & 2 & 2 & 0 & 4 \\
\hline & In course & 0 & 0 & 1 & 0 & 1 \\
\hline & Hospital & 10 & 5 & 2 & 0 & 17 \\
\hline
\end{tabular}




\section{STRADA Jurnal Ilmiah Kesehatan}

DOI: $10.30994 /$ sjik.v9i2.469

ISSN: 2252-3847 (print); 2614-350X (online)

Vol.9 No.2 November 2020 Page.1370-1379

\begin{tabular}{llllll}
\hline 3 & Period of death & & & & \\
Pregnant & 2 & 2 & 1 & 0 & 5 \\
Childbirth & 0 & 0 & 0 & 0 & 0 \\
Post-partum & 8 & 5 & 3 & 1 & 17 \\
\hline
\end{tabular}

Table 3. Showed that the majority of mothers with preventable maternal deaths were 11 cases $(50 \%)$, while 11 cases $(50 \%)$ unpreventable. The place of maternal death mostly occurred in the hospital as many as 17 cases $(77.3 \%)$, in the course of 1 case $(4.5 \%)$, and at home as many as 4 cases $(18.2 \%)$. In the period of maternal death, most of them occurred in the puerperium period, 17 cases $(77.3 \%)$ and the pregnancy period in 5 cases $(22.7 \%)$.

Table 4. Profiles of Causes of Maternal Deaths Indirect Causes that can be Prevented in the City of Bandung

\begin{tabular}{|c|c|c|c|c|c|}
\hline \multirow{3}{*}{ No. } & \multirow{3}{*}{ Category } & \multicolumn{3}{|c|}{ Indirect Cause $n=4$} & \multirow{3}{*}{$\begin{array}{c}\text { Total } \\
\mathbf{n}\end{array}$} \\
\hline & & \multirow{2}{*}{$\begin{array}{c}\begin{array}{c}\text { Heart } \\
\text { disease }\end{array} \\
n\end{array}$} & \multirow{2}{*}{$\begin{array}{c}\begin{array}{c}\text { Bronco } \\
\text { Pneumonia }\end{array} \\
\mathbf{n}\end{array}$} & \multirow{2}{*}{$\begin{array}{c}\text { Anemia } \\
\mathbf{n}\end{array}$} & \\
\hline & & & & & \\
\hline \multirow[t]{3}{*}{1} & Maternal Death & & & & \\
\hline & Unpreventable & 0 & 0 & 0 & 0 \\
\hline & Preventable & 2 & 1 & 1 & 4 \\
\hline \multirow[t]{4}{*}{2} & Death place & & & & \\
\hline & House & 0 & 0 & 0 & 0 \\
\hline & In course & 0 & 0 & 0 & 0 \\
\hline & Hospital & 2 & 1 & 1 & 4 \\
\hline \multirow[t]{4}{*}{3} & Period of death & & & & \\
\hline & Pregnant & 0 & 0 & 0 & 0 \\
\hline & Childbirth & 0 & 0 & 0 & 0 \\
\hline & Post-partum & 2 & 1 & 1 & 4 \\
\hline
\end{tabular}

Table 4. Showed that most of the mothers with indirect causes of maternal death that can be prevented were 4 cases (100\%), where most of the maternal deaths occurred in hospitals as many as 2 cases (50\%), during the period of maternal deaths in the childbirth were 2 cases $(50 \%)$.

Table 5. The Relationship between Cases and Controls Based on Patient Factors and Maternal Mortality in Bandung City

\begin{tabular}{|c|c|c|c|c|c|c|c|}
\hline \multirow{3}{*}{ No. } & \multirow{3}{*}{ Patient factors } & \multicolumn{4}{|c|}{ Group } & \multirow{3}{*}{$\begin{array}{c}\text { Value } \\
p^{*}\end{array}$} & \multirow{3}{*}{$\begin{array}{c}\text { OR } \\
(\text { CI 95\%) }\end{array}$} \\
\hline & & \multicolumn{2}{|c|}{ Case } & \multicolumn{2}{|c|}{ Control } & & \\
\hline & & $n=26$ & $\%$ & $n=78$ & $\%$ & & \\
\hline \multirow[t]{3}{*}{1.} & Mother's age & & & & & 0,211 & \\
\hline & $<20$ years old and $>35$ years old & 10 & 38,5 & 20 & 25,6 & & $1,81(0,71-4,6)$ \\
\hline & 20-35 years old & 16 & 61,5 & 58 & 74,4 & & \\
\hline \multirow[t]{3}{*}{2.} & Parity & & & & & 0,101 & \\
\hline & 1 or $\geq 4$ children & 4 & 15,4 & 25 & 32,1 & & $0,38(0,12-1,24)$ \\
\hline & $2-3$ children & 22 & 84,6 & 53 & 67,9 & & \\
\hline \multirow[t]{3}{*}{3.} & Birth space & & & & & 0,241 & \\
\hline & $<2$ years & 7 & 26,9 & 12 & 15,4 & & $2,06(0,70-5,86)$ \\
\hline & $\geq 2$ years & 19 & 73,1 & 66 & 84,6 & & \\
\hline \multirow[t]{4}{*}{4.} & Mother's education & & & & & 0,028 & \\
\hline & Primary & 8 & 30,8 & 14 & 17,9 & 0,192 & \\
\hline & Secondary & 14 & 53,9 & 49 & 62,9 & & $2,0(0,7-5,7)$ \\
\hline & High & 4 & 15,4 & 15 & 19,2 & & $2,1(0,5-8,7)$ \\
\hline
\end{tabular}




\section{STRADA Jurnal Ilmiah Kesehatan}

DOI: $10.30994 /$ sjik.v9i2.469

ISSN: 2252-3847 (print); 2614-350X (online)

Vol.9 No.2 November 2020 Page.1370-1379

\begin{tabular}{|c|c|c|c|c|c|c|c|}
\hline \multirow[t]{2}{*}{5.} & Maternal comorbidities & & & & & \multicolumn{2}{|l|}{0,406} \\
\hline & Yes & 4 & 15,4 & 18 & 23,1 & & \\
\hline \multirow{4}{*}{6.} & No & 22 & 84,6 & 60 & 76,9 & \multirow{4}{*}{$\mathbf{0 , 0 1 2}$} & $0,61(0,18-1,99)$ \\
\hline & ANC History & & & & & & \\
\hline & $<4$ times & 8 & 30,8 & $0^{*}$ & $0 *$ & & $37,4(9,5-313,6)$ \\
\hline & $\geq 4$ times & 18 & 69,2 & 78 & 100 & & \\
\hline
\end{tabular}

From table 5 in the control group, history of ANC <4 times was 0 cases, the value of 1 was added to facilitate statistical calculations, so that in the history of ANC, all cases were added 1 . The results of statistical tests showed that there was one who had a relationship with maternal death because it had $\mathrm{p}$ value 0.05 , that was the history of ANC.

Table 6. Relationship between Cases \& Controls and the Amount of Risk Based on Health Facility Factors and Maternal Mortality in Bandung

\begin{tabular}{|c|c|c|c|c|c|c|c|}
\hline \multirow[b]{2}{*}{ No. } & \multirow[b]{2}{*}{ Medical Facility Factor } & \multicolumn{4}{|c|}{ Group } & \multirow[b]{2}{*}{ Value $p^{*}$} & \multirow[b]{2}{*}{$\begin{array}{c}\text { OR } \\
\text { (CI 95\%) }\end{array}$} \\
\hline & & \multicolumn{2}{|c|}{ Case } & \multicolumn{2}{|c|}{ Control } & & \\
\hline \multirow[t]{3}{*}{1.} & Death Place & & & & & \multirow[t]{3}{*}{$<0,001$} & \\
\hline & Medical Facility & 5 & 19,2 & 0 & 0 & & $21,5(2,5-188,5)$ \\
\hline & Non-Medical Facility & 21 & 80,8 & 78 & 100 & & \\
\hline \multirow[t]{3}{*}{2.} & Facility availability & & & & & \multirow{3}{*}{$<0,001$} & \\
\hline & Available & 5 & 21,4 & 1 & 25,6 & & $21,5(2,5-188,5)$ \\
\hline & Not available & 21 & 78,6 & 79 & 74,4 & & \\
\hline \multirow[t]{3}{*}{3.} & Costs & & & & & \multirow[t]{3}{*}{0,369} & \\
\hline & Independent & 6 & 26,9 & 12 & 15,4 & & $1,6(0,54-4,95)$ \\
\hline & Community Health insurance & 20 & 73,1 & 66 & 84,6 & & \\
\hline
\end{tabular}

Note: Based on the two-sample chi square test or Fisher's exact probability

Table 6. In the control group where non-health facilities death and the availability of facilities were not available, it was found that 0 cases, so each must be added a value of 1 to facilitate statistical calculations, so that at the place of death and the availability of facilities, all cases were added 1. The results of statistical tests showed that two Variables related to maternal death, they were the place of death and the availability of facilities because it had a value of $\mathrm{p} \leq 0.05(\mathrm{p}=<0.001)$, while there was 1 variable that was not related or had no relationship to maternal death, namely cost $(\mathrm{p}=0.369)$.

Table 7. Cases and controls relationship between Delayed Referral and Maternal Mortality in Bandung City

\begin{tabular}{|c|c|c|c|c|c|}
\hline \multirow[b]{2}{*}{ No. } & \multirow[b]{2}{*}{ Referral Factors } & \multicolumn{2}{|c|}{ Group } & \multirow[b]{2}{*}{ Value $p^{*}$} & \multirow{2}{*}{$\begin{array}{c}\text { OR } \\
(\text { CI 95\%) }\end{array}$} \\
\hline & & $\begin{array}{l}\text { Case } \\
n=26\end{array}$ & $\begin{array}{c}\text { Control } \\
\mathrm{n}=78\end{array}$ & & \\
\hline & Referral Case & & & $<0,001$ & \\
\hline & Non Referral & 15 & 1 & & $91,2(11,1-750)$ \\
\hline & Referral & 13 & 79 & & \\
\hline \multirow[t]{3}{*}{2.} & Delayed referral & & & & \\
\hline & Delayed & 17 & 1 & $<0,001$ & $122,1(14,7-1010,2)$ \\
\hline & Not delayed & 11 & 79 & & \\
\hline
\end{tabular}

Note: Based on the two-sample chi square test or Fisher's exact probability 


\section{STRADA Jurnal Ilmiah Kesehatan}

DOI: $10.30994 /$ siik.v9i2.469

ISSN: 2252-3847 (print); 2614-350X (online)

Vol.9 No.2 November 2020 Page.1370-1379

Table 7 in the control group, namely non-referral referral cases and 0 cases of delayed referral for each, so the value of 1 must be added to facilitate statistics. The results of statistical tests showed that referral cases and referral delay had a relationship to maternal mortality because they had a value of $\mathrm{p} \leq 0.05(\mathrm{p}=<0.001)$.

\section{DISCUSSION}

Table 1. presented data on the characteristics of maternal mortality. From the group of maternal death cases there were 2 people aged $<20$ years, 10 people aged $>35$ years and 16 people aged 20-35 years. At risk ages ( $<20$ years and $>35$ years) should not plan a pregnancy or delay the pregnancy until the age of 20 years or more. The safest age for a woman to get pregnant and give birth is between the ages of 20-35 years, because they are in a period of healthy reproduction. Maternal mortality that occurs in pregnant women and giving birth at $<20$ years and $>35$ years of age will increase, because they are exposed to both medical and obstetric complications that can endanger their lives. The maternal parity showed that maternal mortality in the case group mostly occurred in parity of 2-3 children as many as 22 cases (84.6\%) and the control group occurred in parity of 2-3 children as many as 53 cases $(67.9 \%)$. Parity at risk is $\leq 1$ or $>4$, parity $\leq 1$ and young age is at risk because the mother is not ready medically or mentally, while parity> 4 and old age physically experienced a decline in reproductive function, but second or third pregnancy if it occurs in circumstances that are not expected that close proximity can increase the risk of maternal death.

In this study, parity is not a risk factor that affects maternal mortality because of the equal proportion of cases and controls.

The results showed that there were 19 cases of maternal mortality in the case group with a pregnancy interval of $\geq 2$ years $(73.1 \%)$ and in the control group with a pregnancy interval of $\geq 2$ years as many as 66 cases $(84.6 \%)$. This showed that the lack of public knowledge about the risk of pregnancy with births that are too far apart, even though the pregnancy distance that is at risk of maternal death is birth spacing $<2$ years.

The results showed that the highest number of maternal deaths was in the case group with secondary education as many as 14 cases (53.9\%) and in the control group with secondary education as many as 49 cases $(62.8 \%)$. The relationship between education and maternal mortality is not straightforward. Education indirectly has an effect on improving the social status and position of mothers in society, increasing choices for life and increasing self-determination and opinion.

The results showed that maternal mortality with comorbidities in mothers, most of them did not have comorbidities as many as 22 cases $(84.6 \%)$ and those with comorbidities were 4 cases (15.4\%). Maternal medical history is defined as a disease that the mother has had before pregnancy, childbirth or an illness that occurs during pregnancy that is not related to the direct obstetric cause, but is exacerbated by the physiological effects of pregnancy so that the mother's condition becomes worse. Maternal death due to illness suffered by the mother is the cause of indirect maternal death.

The results showed that the birth attendants were mostly assisted by health personnel in the case group as many as 26 cases (100\%) and the control group as many as 78 cases $(100 \%)$. The results of the research in Cilacap showed that there were cases of maternal 


\section{STRADA Jurnal Ilmiah Kesehatan}

DOI: $10.30994 /$ siik.v9i2.469

ISSN: 2252-3847 (print); 2614-350X (online)

Vol.9 No.2 November 2020 Page.1370-1379

death related to the inability of health workers to provide medical assistance. The number of inadvertently committed by health workers in providing health services if they make people feel that they are not in accordance with what the community wants will still be seen as a mistake by the community. Therefore, as health workers who will enter the wider community, they must be truly competent.

The results showed that the maternal mortality in the case group mostly occurred with Jamkesmas / BPJS financing as many as 20 cases (76.9\%) and in the control group with Jamkesmas / BPJS financing as many as 66 cases (84.6\%). From the results above, it can be seen that although many have used Jamkesmas / BPJS financing in the case group (76.9\%) and the control group (84.6\%), there are still some cases that have not taken advantage of it.

Table 2. showed the cause of death due to direct obstetric complications caused by bleeding $38.5 \%$ and the most causes of death due to indirect complications caused by heart disease $7.7 \%$. Excessive bleeding after delivery should look for a specific cause. Nonetheless, two thirds of cases of post-partum hemorrhage occur in mothers whose risk factors cannot be identified. Many risk factors have been associated with ante partum hemorrhage and post-partum hemorrhage, however it is very important for early identification of risk factors because ante partum hemorrhage and postpartum hemorrhage remain significant contributors to morbidity and mortality worldwide. The main risk for pregnant women with heart disease is the possibility of having a heart attack during pregnancy that causes death. The risks to the baby are unknown, although some drugs used in the treatment of coronary heart disease or diabetes and high blood pressure can affect the baby's condition.

Table 3. The causes of direct maternal death that can be prevented are 11 out of 22 deaths due to direct causes, which mostly occurred in the puerperium period, 17 cases and 17 cases occurred in hospital. Obstetric complications are illnesses in pregnant women, women giving birth, postpartum mothers, and / or fetuses in the womb, either directly or indirectly, including infectious and non-infectious diseases that can threaten the life of the mother and or the fetus. Prevention and management of obstetric complications is services for mothers with obstetric complications to receive definitive protection and treatment according to standards by competent health personnel at the basic and referral service levels.

Table 4 showed the indirect preventable causes of death as many as 4 out of 4 cases of death which mostly occurred in the hospital as many as 4 cases with 2 cases of postpartum period. Maternal deaths are classified as preventable if the mother is treated according to procedures, if there is no malfunctioning of the health system or delays in patient care. Unpreventable deaths include accidental death from anaphylactic shock, organ failure due to diseases such as cancer, kidney failure or acute complications, liver necrosis, intravascular coagulation. Amniotic fluid embolism is unpredictable / preventable even in developed countries, although it cannot be prevented, China has the potential to improve the prognosis of amniotic fluid embolism by strengthening the obstetric emergency care system.

Table 5 showed that there was a relationship between history of ANC and maternal mortality as indicated by the value of $\mathrm{p}=0.012$, regular ANC examinations, at least 4 


\section{STRADA Jurnal Ilmiah Kesehatan}

DOI: $10.30994 /$ sjik.v9i2.469

ISSN: 2252-3847 (print); 2614-350X (online)

Vol.9 No.2 November 2020 Page.1370-1379

times during pregnancy by health workers according to the time so far only seen from the number of visits that were appropriate and said to be good, but rarely judging from the quality and results of the mother's visit, namely the understanding and awareness of pregnant women regarding conditions of pregnancy, childbirth and post-partum so that it affects decisions that have an impact on handling if problems or complications occur.

Table 6. showed that there was a relationship between the place of death $(\mathrm{p}=<0.001)$ and the availability of facilities $(\mathrm{p}=<0.001)$ with maternal mortality. Based on the health profile of Bandung City in 2015, the number of deliveries assisted by competent midwifery health workers was 46. 128 so the maternal mortality in Bandung was 26 / $46,128 \times 100,000=56$ of 100,000 live births. The facilities for the availability of facilities in the city of Bandung are already good and are somewhat more complete than in other regions. The problem is that in the referral process, especially emergency obstetric care, it must be carried out appropriately and must avoid three delays, so that in the process of utilizing the facilities it can be used more optimally.

Table 7. showed that there was a relationship between referral cases $(\mathrm{p}=<0.001)$ and delay in referral $(\mathrm{p}=<0.001)$ with maternal mortality. The referral system, especially in midwifery emergency services, must be carried out appropriately and must avoid three delays, namely delays in decision making, delays in reaching the referral destination and delays in obtaining services at the referral place. Delay in referral to mothers who experience complications during pregnancy, childbirth and the post-partum provides a greater risk of maternal death when compared to mothers who do not experience late referral when complications occur. Delays in referral in cases of maternal death include delays in the first, second and third (3T). This delay (3T) will worsen the condition of the mother due to the fact that the mother cannot get adequate treatment in accordance with the existing complications, so that maternal death is unavoidable.

\section{CONCLUSION}

Based on the research results, there was a relationship among ANC history, place of death, availability of facilities, referral cases and late referral to maternal death.

\section{REFERENCES}

Barat DKJ. 2014. Profil Kesehatan Jawa Barat.

Indonesia KKR. 2015. Rencana Strategis Kementerian Kesehatan tahun 2015-2019.

Jablensky A. 1989. The tenth revision of the International Classification of Diseases (ICD-

10). Classification and Diagnosis of Alzheimer Disease, An international approach, Hogrefe \& Huber Publ, Toronto. 53-7

Kementerian Kesehatan R. 2013. Profil Kesehatan Indonesia 2012. Jakarta: Kementerian Kesehatan RI.

Merali HS, Lipsitz S, Hevelone N, Gawande AA, Lashoher A, Agrawal P, et al. 2014. Audit-identified avoidable factors in maternal and perinatal deaths in low resource settings: a systematic review. BMC pregnancy and childbirth. 14(1):1. http://www.biomedcentral.com/1471-2393/14/280 


\section{STRADA Jurnal Ilmiah Kesehatan}

DOI: $10.30994 /$ sjik.v9i2.469

ISSN: 2252-3847 (print); 2614-350X (online)

Vol.9 No.2 November 2020 Page.1370-1379

Organization WH, UNICEF. 2014. Trends in maternal mortality: 1990 to 2013: estimates by WHO, UNICEF, UNFPA, The World Bank and the United Nations Population Division: executive summary.

Profil Kota Bandung. 2014.

WHO. 2015. Care of the preterm and/or low-birth-weight newborn 2015. 